Original Contribution

\title{
a-AMYLASE ACTIVITY IN THE SALIVARY GLANDS AND THE MIDGUT OF APODIPHUS AMYGDALI GERMAR (HEMIPTERA: PENTATOMIDAE)
}

\author{
S. Ramzi $^{1}$, A. Zibaee ${ }^{2 *}$ \\ ${ }^{1}$ Plant Protection Research Department, Horticultural Science Research Institute, Tea Research Center, \\ Agricultural Research Education and Extension Organization (AREEO), Lahijan, Iran. \\ ${ }^{2}$ Department of Plant Protection, Faculty of Agricultural Sciences, University of Guilan, Rasht, Iran
}

\begin{abstract}
In the current study, activities of $\alpha$-amylase were determined and characterized in the salivary glands and the midgut of an orchard pest, Apodiphus amygdali. It was found that activity of the $\alpha$-amylase in midgut was statistically higher than that of salivary glands. Optimal $\mathrm{pH}$ of amylolytic activities were obtained to be 8 for salivary glands and 5 for midgut. The enzymes extracted from salivary glands and midgut had the highest activities at temperatures of 45 and $40{ }^{\circ} \mathrm{C}$, respectively. Mono- and di-valent cations significantly changed amylolytic activities in the midgut and salivary glands of $A$. amygdali. In case of salivary glands, $\mathrm{Na}^{+}, \mathrm{K}^{+}$and $\mathrm{Mg}^{2+}$ showed no effects but $\mathrm{Ca}^{2+}$ and $\mathrm{Cu}^{2+}$ increased the enzymatic activity. $\mathrm{Na}^{+}$and $\mathrm{Mg}^{2+}$ decreased midgut $\alpha$-amylase of $A$. amygdali but $\mathrm{Ca}^{2+}$ showed adverse results. Lieweaver-Burk analysis of the enzyme in salivary glands and midgut revealed $\mathrm{V}_{\max }$ of 11.23 and 5.88 (U/mg protein) as well as $\mathrm{K}_{\mathrm{m}}$ of 6.85 and $2.58(\%)$, respectively. Since $\alpha$-amylase has critical role in carbohydrate digestion of insects, those have been targeted by several researches to develop inhibitors in resistant varieties. But characterization of the enzymes is the initial and major step to reach such an objective.
\end{abstract}

Key words: Apodiphus amygdali, $\alpha$-amylase, characterization

\section{INTRODUCTION}

Digestion in insects is a multiple steps that ingested macromolecules are broken down as monomers to be absorbed via epithelial cells of midgut. Several macromolecules such as carbohydrates, proteases and lipids are ingested that require relevant enzymes, carbohydrases, proteases and lipases, to be digested. Carbohydrases are divided into several enzymes like amylases, $\beta$-Glucanases, Xylanases and Pectinases, Chitinases and Lysozymes, $\alpha$-Glucosidases, $\beta$-Glucosidases and $\quad \beta$-Galactosidases, $\quad$ Trehalases, Acetylhexosaminidases, $\beta$-Fructosidases and $\alpha$-Galactosidases (1). In case, $\alpha$-amylase seems to be more crucial since they are the first enzymes that encounter carbohydrates in the midgut because the enzymes break macromolecule from internal bonds. $\alpha$ Amylases (EC 3.2.1.1) are a type of hydrolyzes that catalyze breaking-down of starch and glycogen from inner long $\alpha$-1,4-glucan chains

\footnotetext{
*Correspondence to: Arash Zibaee, Department of Plant Protection, Faculty of Agricultural Sciences, University of Guilan, Rasht, Iran. 416351314, arash.zibaee@gmx.com,arash.zibaee@guilan.ac.ir
}

(2). General properties of the enzymes are molecular weight of 48-60 kDa, pI values of 3.5-4.0, and $\mathrm{K}_{\mathrm{m}}$ values with soluble starch around $0.1 \%$ (1). Meanwhile, the enzyme is calcium-dependent and it is activated by chloride with displacement of the $\mathrm{pH}$ optimum (1).

Apodiphus amygdali Germar (Hemiptera: Pentatomidae) is an hemipteran pest of fruit trees by wide distribution in Europe and Middle East (3). Host trees contains plum, apricot, apple, olive, pear and pistachio in addition to non-fruit trees like poplar, pine, plane-tree, elm and willow bark (3). A. amygdali utilize salivary secretions to liquefy plant tissues, pump the liquid food to its midgut where the main digestive process are made by recruiting relevant enzymes. Feeding activities of the pest causes host weakness and attracts other insects to feed on host plants. Feeding on fruits causes complete degradation and yield loss (4).

Spraying of chemical insecticides leads to severe concerns like resistant of pest to used chemicals, environmental pollution, effects on 
non-target organisms, chemical residues in agricultural products and etc. This point goes to be more critical when direct spraying are made on trees where their fruits are consumes by human. Hence, adoption of other control procedures seems to be important. One of the promising pest control could be development of resistant varieties by using inhibitors of digestive enzymes. $\alpha$-Amylase is one of the targeted digestive enzymes to develop inhibitors. There are Six different $\alpha$-amylase inhibitors in insect control including lectinlike, knottin-like, cereal-type, Kunitz-like, cpurothionin-like, and thaumatin-like that may be useful in pest control (5). These inhibitors show structural diversity, different modes of inhibition, and different specificity profiles against a diverse range of $\alpha$-amylases (5). To reach such an objective, characterization of target enzymes is mandatory to design or screen of an inhibitor. So, the objective of the current study were to determine amylolytic activity in the salivary glands and the midgut of $A$. amygdali, optimal $\mathrm{pH}$ and temperature for enzymatic activity, effects of cations and kinetic study.

\section{MATERIALS AND METHODS}

Fifth nymphal instars of $A$. amygdali was collected from elm trees in Shiraz (Fars province) and transferred to laboratory. Then, the nymphs were reared on elm leaves at $28 \pm 1$ ${ }^{\circ} \mathrm{C}, \quad 70 \%$ of humidity and $16 \quad \mathrm{~L}: 8 \mathrm{D}$ photoperiods. Adults were randomely selected and used for biochemical experiments.

\section{Sample preparation}

Dissection of adults were carried out by the method of Cohen (6). Salivary glands and midgut of $A$. amygdali were removed by dissection using a stereomicroscope in ice-cold saline buffer $(\mathrm{NaCl}, 10 \mathrm{mM})$. Removed tissues were rinsed in $1 \mathrm{~mL}$ of ice-cold distilled water in the portions of five midgut and ten salivary glands. Tissues were grounded by an homogeniszer and centrifuged in 13,000 rpm for $20 \mathrm{~min}$ at $4{ }^{\circ} \mathrm{C}$. Supernatant was carefully removed and transferred to new tubes and stored at $-20{ }^{\circ} \mathrm{C}$ for subsequent experiments.

\section{$\alpha$-Amylase assay}

The method described by Bernfeld (7) was used to determine $\alpha$-amylase activity in the salivary glands and the midgut of $A$. amygdali. Briefly, $10 \mu \mathrm{l}$ of the enzyme were incubated for $30 \mathrm{~min}$ at $35{ }^{\circ} \mathrm{C}$ with $50 \mu \mathrm{l}$ of universal buffer $(20 \mathrm{mM}$, Glycin, Succinate and 2morpholinoethan sulfuric acid, $\mathrm{pH}$ 7) and $40 \mu \mathrm{l}$ of soluble starch $(1 \%)$. The reaction was stopped by adding of $100 \mu \mathrm{l}$ dinitrosalicylc acid and heating in boiling water for $10 \mathrm{~min}$ prior to read absorbance at $545 \mathrm{~nm}$. One unit of $\alpha$-amylase activity was defined as the amount of enzyme required to produce $1 \mathrm{mg}$ maltose in 30 min at $35^{\circ} \mathrm{C}$. A blank without substrate but with $\alpha$-amylase extract and a control containing no $\alpha$-amylase extract but with substrate were measured at the same time as the reaction mixtures.

\section{Determination of optimal temperature and pH of the enzyme}

The effects of temperature and $\mathrm{pH}$ on $\alpha$ amylase activities in $A$. amygdali were determined by incubation of the reaction mixture in various temperature and $\mathrm{pH}$ sets. The effect of temperature was determined by incubating the reaction mixture at $15,20,25$, $30,35,40,45,50,55$ and $6070{ }^{\circ} \mathrm{C}$ for $30 \mathrm{~min}$. Optimal $\mathrm{pH}$ was determined using universal buffer with $\mathrm{pH}$ set at $3,4,5,6,7,8,9,10,11$, and 12. Other steps were carried out as described earlier.

\section{Effect of different cations on $\alpha$-amylase activity}

Different concentrations of mono- and divalent cations $(0,1,3$ and $5 \mathrm{mM})$ were assayed to find their possible effects on the enzymatic activity. Used cations were $\mathrm{Na}+, \mathrm{K}+, \mathrm{Ca} 2+$, $\mathrm{Cu} 2+$ and $\mathrm{Mg} 2+$. Reaction mixture contained $50 \mu \mathrm{l}$ of universal buffer, $20 \mu \mathrm{l}$ of substrate, 20 $\mu \mathrm{l}$ of ion concentration and $10 \mu \mathrm{l}$ of the enzyme. The experiment continued as described earlier.

\section{Determination of kinetic values}

Different concentrations of starch $(0.2,0.4$, $0.6,0.8$ and $1 \%$ ) were prepared and enzymatic activity was determined from samples of salivary glands and midgut. Obtained data were inserted in Sigma-Plot software to calculate $\mathrm{V}_{\max }$ and $\mathrm{K}_{\mathrm{m}}$ values.

\section{Protein assay}

Protein concentrations were assayed according to the method described by Lowry et al. (8).

\section{Statistical analysis}

All data were compared by one-way analysis of variance followed by Tukey's test when significant differences were found at $p \geq 0.05$ and marked in figures and tables with letters.

\section{RESULTS AND DISCUSSION}

Adults of $A$. amygdali was dissected under a stereomicroscope revealing an alimentary canal consists a four-sectioned midgut $\left(\mathrm{V}_{1}-\mathrm{V}_{4}\right)$ (Figure 1). V1, V3 and V4 are the slender sections but V2 is a bulk-like section (Figure 1). Results of the biochemical experiments revealed significant presence of $\alpha$-amylase in the salivary glands and the midgut of $A$. 
RAMZI S., et al.

amygdali adults so that the enzyme had higher activity in the midgut than the salivary glands (Figure 2). The obtained results were expectable since $A$. amygdali fed on plant tissues in which starch is the main storage components. Meanwhile, amylase of hemipteran salivary glands has major role in liquefying of plant tissues and the final and complete digestion of starch is made in midgut $(9,10)$. Several studies have reported presence of amylases in salivary glands and midgut of hemipterans. Mehrabadi et al. (11) determined amylolytic activity in the salivary glands and the midgut of Eurygaster integriceps Puton (Hemiptera: Scutelleridae). Zibaee et al. (9) and Sorkhabi-Abdolmaleki et al. (12) reported amylolytic activity in saliva and midgut of Andrallus spinidens Fabricius (Hemiptera: Pentatomidae).

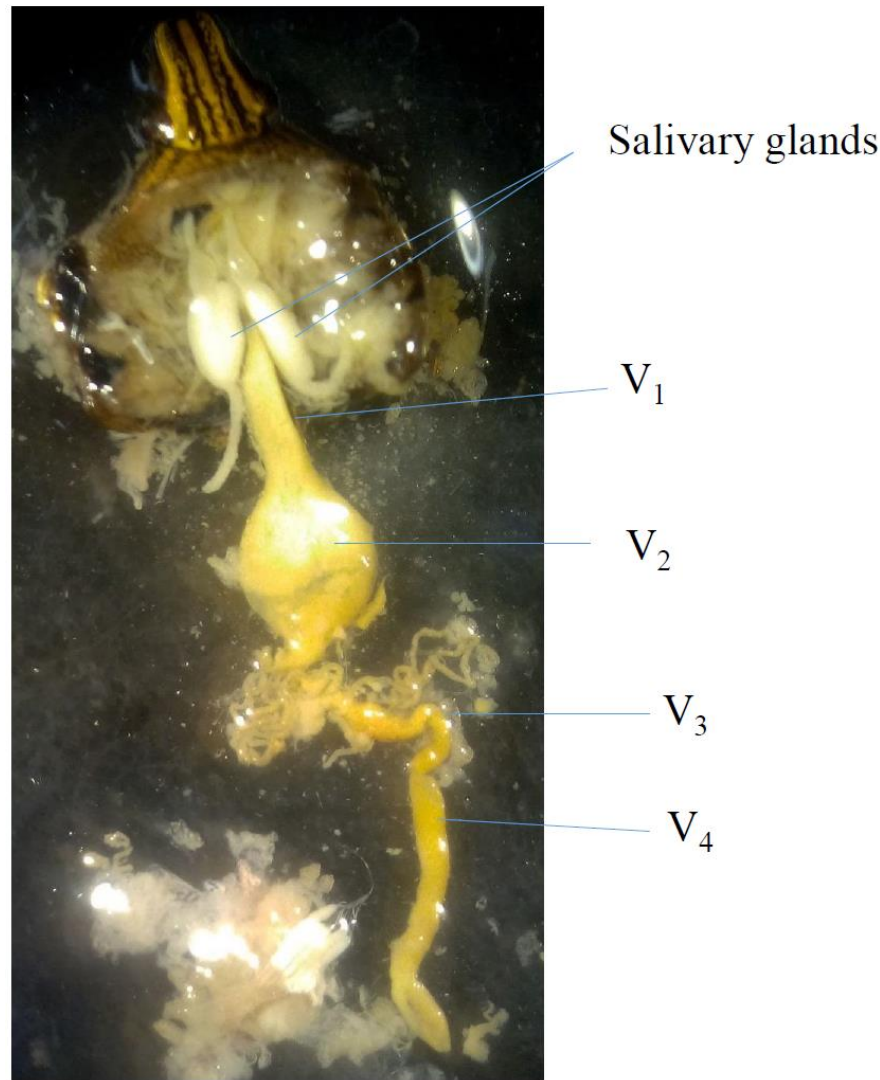

Figure 1. Morphology of the alimentary canal in the adults of Apodiphus amygdali.

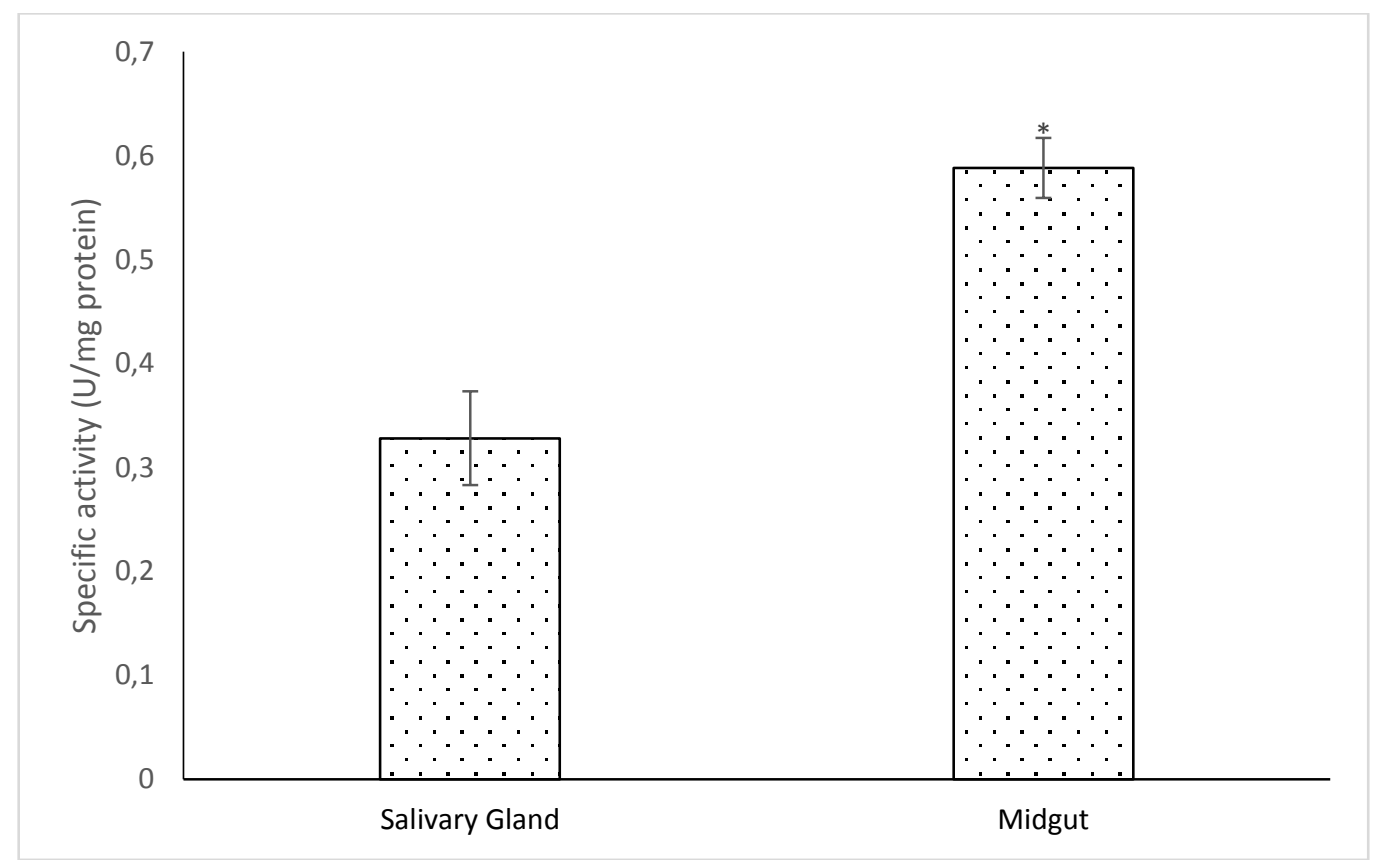

Figure 2. Comparison of amylolytic activity in the salivary glands and the midgut of A. amygdali. Statistical differences have been shown by asterisk (t-test, $p \leq 0.05$ ). 
RAMZI S., et al.

Enzymes showed various reaction toward substrates and inhibitors when they are exposed in various $\mathrm{pH}$ and temperature. Our results indicated that $\alpha$-amylase in the salivary and the midgut of $A$. amygdali showed the highest activities in pHs 8 and 5, respectively (Figure 3; F: F: 74.32, Pr>F: 0.0001; F: 13.68, Pr $>F:$ 0.0002). Meanwhile, activity of the enzyme from both sources increased from temperature $15{ }^{\circ} \mathrm{C}$ to optimal value then sharply decreased so that Optimal temperature of the salivary and midgut $\alpha$-amylases were found 45 and $40{ }^{\circ} \mathrm{C}$, respectively (Figure 4; F: 97.32, Pr>F: 0.0001; F: 64.56, F: 0.0001).
Bandani et al. (13) found optimal $\mathrm{pH}$ of 6.5 and optimal temperature of $25-40{ }^{\circ} \mathrm{C}$ for purified $\alpha$-amylase in the midgut of E.integriceps. Bezdi et al. (14) demonstrated optimal $\mathrm{pH}$ of 4.5 so salivary $\alpha$-amylase activity in E. integriceps. Zeng and Cohen (15) reported optimal $\mathrm{pH}$ of 6 for $\alpha$-amylase of Lygus herperus and L. lineolaris. Zibaee et al. (9) and Sorkhabi-Abdolmaleki et al. (12) found optimal pHs of 8 and 7 for salivary and midgut $\alpha$-amylase of $A$. spinidens. In case of temperature, obtained values are similar to finding on other hemipterans like $E$. integriceps, Lygus spp and A. spinidens (9-15).

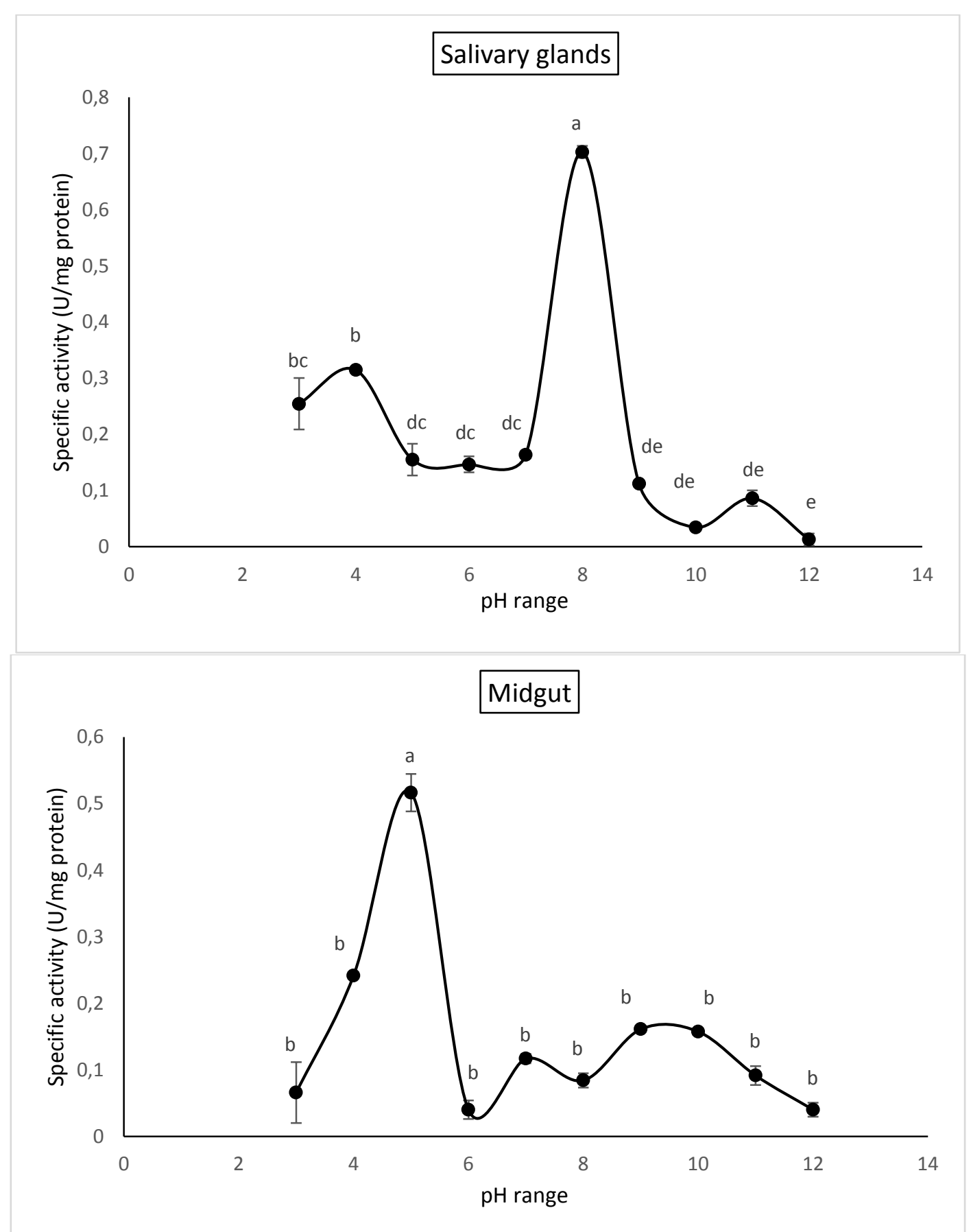

Figure 3. Optimal pH determination of $\alpha$-amylase in the salivary glands and the midgut of A. amygdali. Statistical difefrences have been shown by various letter (Tukey test, $p \leq 0.05$ ). 


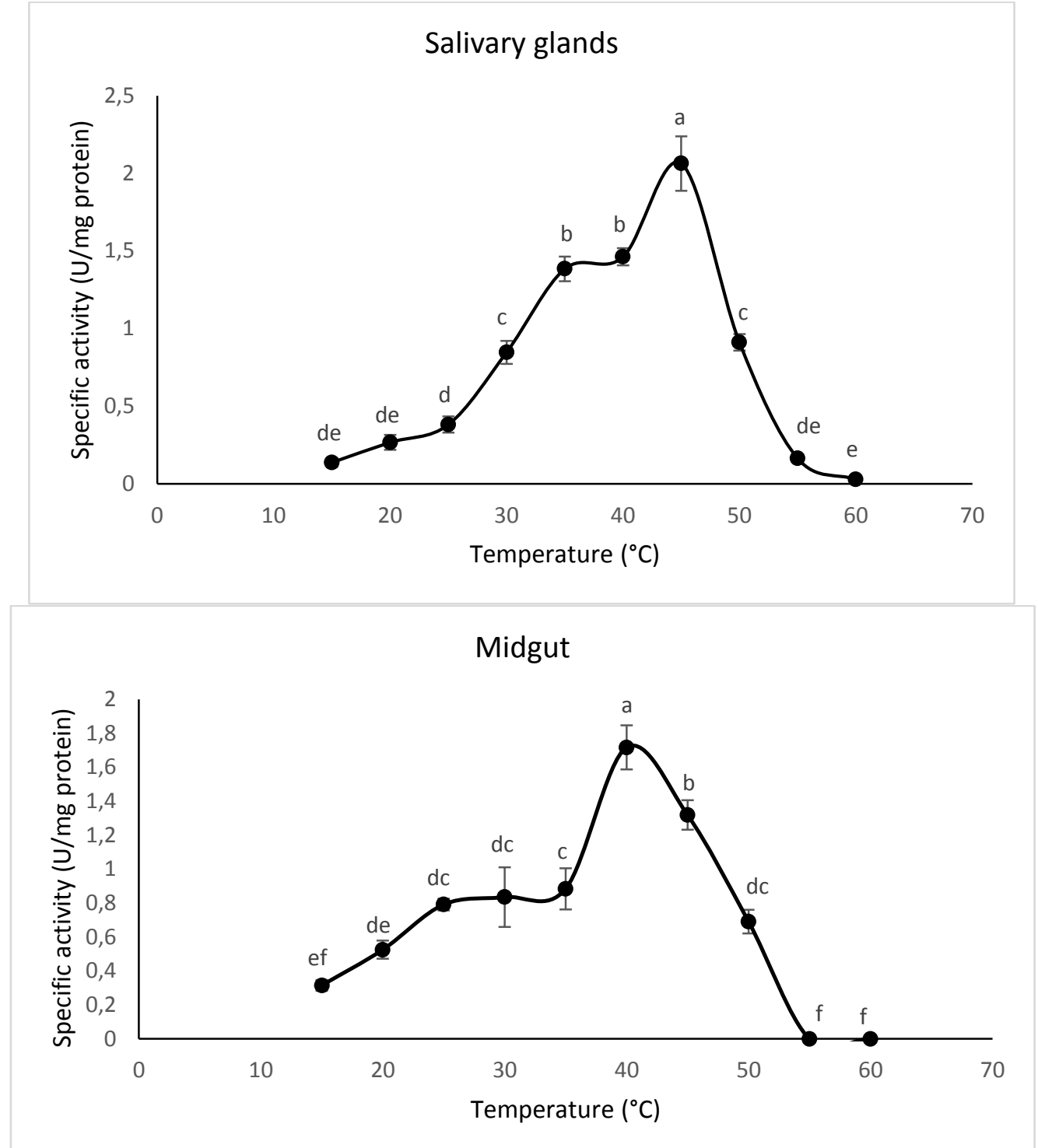

Figure 4. Optimal temperature $\left({ }^{\circ} \mathrm{C}\right)$ determination of $\alpha$-amylase in the salivary glands and the midgut of $A$. amygdali. Statistical difefrences have been shown by various letter (Tukey test, $p \leq 0.05$ ).

In agro-ecosystems, many fertilizers are used to improve quality and quantity of agricultural products. These compounds could affect various physiological processes of insects i.e. enzymatic activities. Moreover, many enzymes recruit ions in their active site or ions could serve as cofactors and increase or sometimes decrease the enzymatic activity. In the current study, Mon- and di-valent cations significantly changes amylolytic activities in the midgut and salivary glands of $A$. amygdali. In case of salivary glands, $\mathrm{Na}^{+}, \mathrm{K}^{+}$and $\mathrm{Mg}^{2+}$ showed no effects but $\mathrm{Ca}^{2+}$ and $\mathrm{Cu}^{2+}$ increased the enzymatic activity (Table 1 ). $\mathrm{Na}^{+}$and $\mathrm{Mg}^{2+}$ decreased midgut $\alpha$-amylase of $A$. amygdali but $\mathrm{Ca}^{2+}$ showed adverse results (Table 1). Taken collectively, it can be concluded that $\mathrm{Ca}^{2}$ had critical role in amylolytic activity of $A$. spinidens salivary glands and midgut. Similar results have been observed in case of $E$. integriceps and $A$. spinidens $(9,12,13)$.
Linweaver-Burk analysis to show kinetic parameters of salivary and midgut $\alpha$-amylase in A. spinidens revealed $\mathrm{V}_{\max }$ of 11.23 and 5.88 (U/mg protein) as well as $\mathrm{K}_{\mathrm{m}}$ of 6.85 and 2.58 (\%), respectively (Figure 5). $\mathrm{K}_{\mathrm{m}}$ has an inverse relationship with the substrate concentration to saturate active sites of the enzyme. On the other hand, lower $\mathrm{K}_{\mathrm{m}}$ reveal stronger binding of enzyme to substrate for degradation. Moreover, higher value of $\mathrm{V}_{\max }$ demonstrates ability of the enzyme to reach the highest velocity for substrate degredation. In our study, $\alpha$-amylase of salivary glands had the highet $\mathrm{V}_{\max }$ but $\alpha$-amylase of the midgut had the lower $\mathrm{K}_{\mathrm{m}}$. It could be concluded that higher velocity of salivary $\alpha$-amylase enable insect to faster liquefaction of plant tissues but lower $\mathrm{K}_{\mathrm{m}}$ of midgut $\alpha$-amylase enable the insect to efficient digestion of ingested carbohydrates. 
Table 1. Effects of mono- and di-valent cations on $\alpha$-amylase activities in the salivary glands and the midgut of A. amygdali.

\begin{tabular}{cccc}
\hline Cation & Concentration & Salivary glands & Midgut \\
\hline $\mathrm{Na}^{+}$ & Control & $100 \pm 10.59 \mathrm{a}$ & $100 \pm 3.69 \mathrm{a}$ \\
& 1 & $84 \pm 10.33 \mathrm{a}$ & $99 \pm 2.57 \mathrm{a}$ \\
& 3 & $81 \pm 3.65 \mathrm{a}$ & $91 \pm 6.45 \mathrm{ab}$ \\
$\mathrm{K}^{+}$ & 5 & $84 \pm 1.94 \mathrm{a}$ & $76 \pm 2.43 \mathrm{~b}$ \\
& Control & $100 \pm 16.53 \mathrm{a}$ & $100 \pm 6.27 \mathrm{a}$ \\
& 1 & $100 \pm 8.83 \mathrm{a}$ & $101 \pm 3.70 \mathrm{a}$ \\
$\mathrm{Ca}^{2+}$ & 3 & $116 \pm 14.31 \mathrm{a}$ & $99 \pm 2.68 \mathrm{a}$ \\
& 5 & $127 \pm 2.88 \mathrm{a}$ & $113 \pm 5.49 \mathrm{a}$ \\
& Control & $100 \pm 5.51 \mathrm{c}$ & $100 \pm 4.14 \mathrm{~b}$ \\
& 1 & $113 \pm 1.78 \mathrm{bc}$ & $86 \pm 1.67 \mathrm{~b}$ \\
$\mathrm{Mg}^{2+}$ & 3 & $133 \pm 8.43 \mathrm{~b}$ & $93 \pm 6.92 \mathrm{~b}$ \\
& 5 & $174 \pm 7.03 \mathrm{a}$ & $123 \pm 1.34 \mathrm{a}$ \\
& Control & $100 \pm 5.41 \mathrm{a}$ & $100 \pm 1.35 \mathrm{ab}$ \\
$\mathrm{Cu}^{2+}$ & 1 & $80 \pm 4.82 \mathrm{a}$ & $90 \pm 1.35 \mathrm{~b}$ \\
& 3 & $89 \pm 9.86 \mathrm{a}$ & $117 \pm 4.86 \mathrm{a}$ \\
& 5 & $88 \pm 3.87 \mathrm{a}$ & $98 \pm 6.19 \mathrm{~b}$ \\
& Control & $100 \pm 3.14 \mathrm{~b}$ & $100 \pm 1.70 \mathrm{a}$ \\
& 1 & $91 \pm 2.98 \mathrm{~b}$ & $105 \pm 13.52 \mathrm{a}$ \\
& 3 & $112 \pm 1.64 \mathrm{a}$ & $108 \pm 3.82 \mathrm{a}$ \\
& 5 & $111 \pm 1.34 \mathrm{a}$ & $104 \pm 0.89 \mathrm{a}$ \\
\hline
\end{tabular}

*. Statistical differences have been shown by various letters (Tukey test, $p \leq 0.05$ ).

Salivary glands

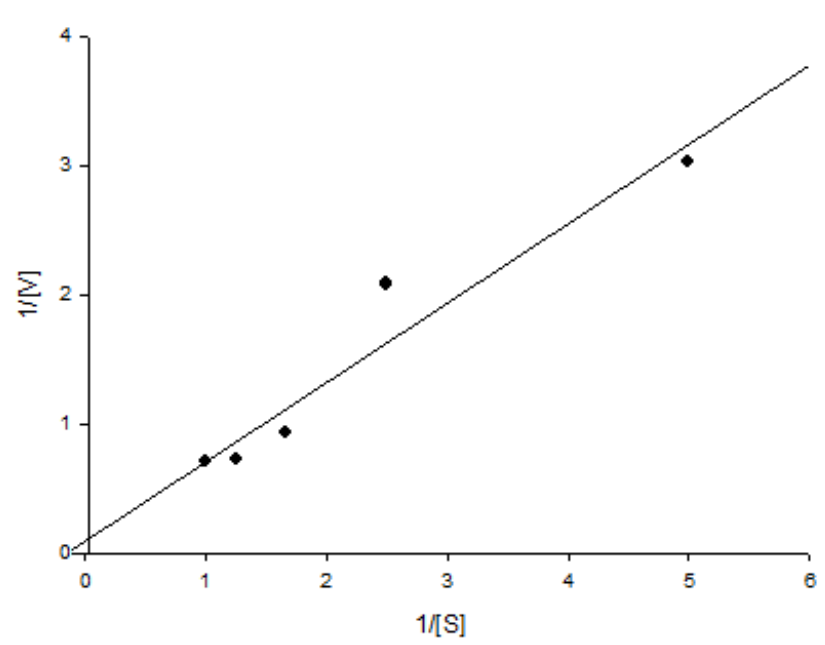

Midgut

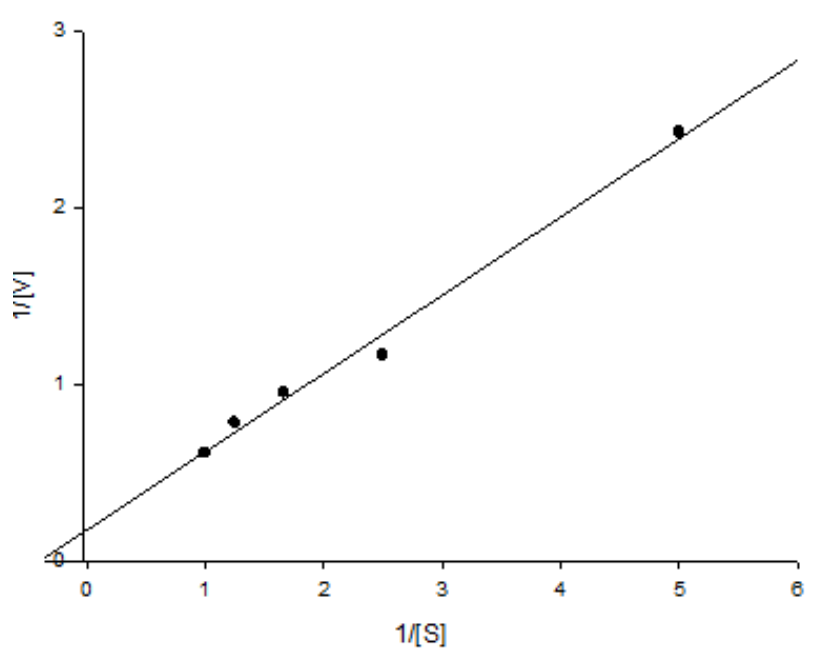

Figure 5. Linweaver-Burk plots sjowing kinetic parameters of $\alpha$-amylase in the salivary glands and in the midgut of A. amygdali.

\section{CONCLUSIONS}

Results of the current study clearly depicted presence of $\alpha$-amylase as one of the major enzymes in the midgut of $A$. amygdali. Determination of amylolytic activities in insects is one of the main steps to develop a safe and efficient pest control. Finding of enzyme properties will be helpful to obtain an inhibitor to decrease enzymatic activity leading to mal-nutrition of target pest. In case, screening of various medicinal plants will be helpful to extract inhibitors like lectins to inhibit amylolytic activity in A. amygdali and suppress population outbreaks of the pest.

\section{REFERENCES}

1. Terra, W. R. and Ferriera, C., Biochemistry of digestion. In: Gilbert LI, Editor. Insect molecular biology and biochemistry, volume. pp. 365-418. Elsevier, 2012

2. Nation, J.L., Digestion. In: Insect Physiology and Biochemistry CRC Press, Boca Raton 27-63, 2008

3. Muhammed, S. H. and Al-Iraqi, R. A., The biology of the stink bug Apodiphus 
amygdali Germar (Hemiptera: Pentatomidae). Mesopotomia. J Agri., 38:1-11, 2010.

4. Schuh RT, Slater JA. 1995. True bugs of the world. Ithaca (NY): Cornell University Press.

5. Franco, O.L., Ridgen, D.J., Melo, F.R., Bloch, C. Jr., Silva, C.P. and Grossi-de-Sa, M.F., Activity of wheat $\alpha$-amylase inhibitors towards bruchid $\alpha$-amylases and structural explanation of observed specificities. Eur. J. Biochem., 267 (8): 2166-2173, 2002.

6. Cohen, A. C., Organization of digestion and preliminary characterization of salivary trypsin like enzymes in a predaceous Heteropteran, Zelus renadii. J. Insect Physiol., 39:823-829, 1993.

7. Bernfeld, P., Amylases, $\alpha$ and $\beta$. Method. Enzym., 1: 149-158, 1955.

8. Lowry, O. H., Rosebrough, N. J., Farr, A. L. and Randall, R. J., Protein measurement with the folin-phenol reagent. J. Biol. Chem., 193:265-275, 1951.

9. Zibaee, A., Hoda, H. and Fazeli-Dinan, M., Purification and biochemical properties of a salivary $\alpha$-amylase in Andrallus spinidens Fabricius (Hemiptera: Pentatomidae). Invert. Surv. J., 9: 48-57, 2012.

10.Somadder, K. and Shrivastava, M., Digestive enzymes in the gut and salivary gland of the larvae of Chilo auricilius
Ddgn. Cell Mol. Life Sci., 36: 218-223, 1980.

11.Mehrabadi, M., Bandani, A. R., Saadati, F. and Ravan, S., Sunn pest, Eurygaster integriceps Putton (Hemiptera: Scutelleridae), digestive $\alpha$-amylase, $\alpha$ glucosidase and $\beta$-glucosidase. J. AsiaPacific. Entomol., 12: 79-83, 2009.

12.Sorkhabi-Abdolmaleki, A., Zibaee, A., Hoda, H. and Fazeli-Dinan, M., Purification and characterization of a digestive $\alpha$ amylase in a predatory bug, Andralus spinidens Fabricius (Hemiptera: Pentatomidae). J. Insect Sci., 14(65). Available online: http://www.insectscience.org/14.65, 2014.

13.Bandani, A.R., Kazzazi, M. and Mehrabadi, M., Purification and characterization of midgut a-amylases of Eurygaster integriceps. Entomol. Sci., 12: 43-50, 2009.

14.Bezdi, M.S., Pourabad, R.F., Sadeghi, H. and Golmohammadi, G., Some properties of $\alpha$-amylase in the salivary glands of Eurygaster integriceps Puton (Hemiptera: Scutelleridae). Munis. Entomol. Zool., 3: 733-744, 2008.

15.Zeng, F. and Cohen, A.C., Partial characterization of a-amylase in the salivary glands of Lygus hesperus and L. lineolaris. Comp. Biochem. Physiol. B., 126: 9-16, 2000. 